\title{
Kepemilikan Manajerial, Institusional, Dewan Komisaris Independen, Komite Audit dan Kinerja Keuangan Perusahaan Food and Beverage
}

\author{
Bella Riantiarta Agatha1 \\ Fakultas Ekonomi Akuntansi \\ Universitas Islam Batik Surakarta, \\ Indonesia \\ Email: bellariantiartaagatha@gmail.com
}

\author{
Siti Nurlaela ${ }^{2}$ \\ Fakultas Ekonomi Akuntansi \\ Universitas Islam Batik Surakarta, \\ Indonesia
}

\author{
Yuli Chomsatu Samrotun ${ }^{3}$ \\ Fakultas Ekonomi Akuntansi \\ Universitas Islam Batik Surakarta, \\ Indonesia
}

\begin{abstract}
ABSTRAK
Penelitian ini bertujuan untuk menguji dan menganalisis pengaruh kepemilikan manajerial, kepemilikan institusional, dewan komisaris independen, dan komite audit terhadap kinerja keuangan perusahaan makanan dan minuman yang terdaftar di Bursa Efek Indonesia pada periode 2014-2018. Jenis penelitian ini adalah penelitian kuantitatif. Populasi dan sampel yang digunakan oleh semua perusahaan makanan dan minuman yang terdaftar di Bursa Efek Indonesia pada periode 2014-2018 dengan mengambil sampel menggunakan metode purposive sampling diperoleh total 13 perusahaan yang memenuhi kriteria. Teknik analisis data yang digunakan adalah uji regresi linier berganda. Hasil penelitian ini menunjukkan bahwa kepemilikan manajerial, dewan komisaris independen, dan komite audit memiliki pengaruh positif dan signifikan terhadap kinerja keuangan. Sementara kepemilikan institusional tidak berpengaruh pada kinerja keuangan.
\end{abstract}

Kata Kunci: Kinerja Keuangan; Kepemilikan Manajerial; Institusional; Dewan Komisaris Independen; Komite Audit.

\section{Managerial, Institutional Ownership, Independent Board Of Commissioners, Audit Committee And Food And Beverage Financial Performance}

\begin{abstract}
This study aims to examine and analyze the effect of managerial ownership, institutional ownership, independent board of commissioners, and audit committee on the financial performance of food and beverage companies listed on the Indonesia Stock Exchange in the 2014-2018 period. This type of research is quantitative research. The population and sample used by all food and beverage companies listed on the Indonesia Stock Exchange in the 2014-2018 period by taking samples using purposive sampling method obtained a total of 13 companies that met the criteria. The data analysis technique used is multiple linear regression test. The results of this study indicate that managerial ownership, independent boards of commissioners, and audit committees have a positive and significant influence on financial performance. While institutional ownership has no effect on financial performance.
\end{abstract}

Keywords: $\quad$ Financial Performance; Managerial Ownership; Institutional; Independent Board of Commissioners; Audit Committee.

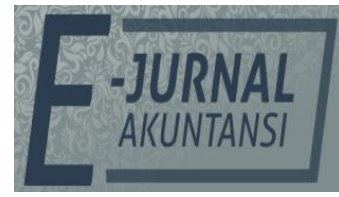

E-JA

e-Jurnal Akuntansi e-ISSN 2302-8556

Vol. 30 No. 7

Denpasar, Juli 2020

Hal. 1811-1826

Artikel Masuk:

5 Juni 2020

Tanggal Diterima: 5 Juli 2020

The Article is Available in : https://ojs.unud.ac.id/index.php/Akuntansi/index 


\section{PENDAHULUAN}

Pertumbuhan penduduk dan perkembangan ekonomi menjadikan sektor makanan dan minuman sebagai lahan paling strategis untuk mendapatkan keuntungan yang tinggi dalam berinvestasi. Alasan pemilihan sektor food and beverage, karena saham-saham makanan dan minuman paling tahan dengan krisis ekonomi dibandingkan sektor lain. Sektor food and beverage ini tetap dibutuhkan masyarakat karena merupakan kebutuhan pokok. Seiring meningkatnya kebutuhan masyarakat, maka kinerja perusahaan juga akan meningkat.

Good Corporate Governance merupakan salah satu elemen kunci dalam meningkatkan kinerja perusahaan, yang meliputi serangkaian hubungan antara manajemen perusahaan, dewan direksi, para pemegang saham, dan stakeholders lainnya. Corporate Governance juga memberikan suatu struktur yang memfasilitasi penentuan sasaran-sasaran dari suatu perusahaan, dan sebagai sarana untuk menentukan teknik monitoring kinerja (Riantono, 2014). Sementara menurut Kusmayadi et al., (2015) good corporate governance merupakan suatu sistem pengelolaan perusahaan yang dirancang untuk meningkatkan kinerja perusahaan, melindungi kepentingan stakeholders dan meningkatkan kepatuhan terhadap peraturan perundang-undangan serta nilai-nilai etika yang berlaku secara umum.

Kinerja keuangan bagi stakeholder suatu perusahaan adalah melihat kinerja yang dihasilkan dalam sektor keuangan berjalan dengan baik. Oleh karena itu perusahaan berkewajiban melakukan pengungkapan kinerja keuangan secara transparan atau tidak disembunyikan berupa Laporan Keuangan. Laporan Keuangan dalam bentuk informasi serta menggambarkan kondisi kinerja dari perusahaan sehingga dapat dijadikan sebagai bentuk dari prestasi. Kinerja keuangan merupakan hasil dari berbagai keputusan secara perorangan yang dibuat terus menerus oleh manajemen perusahaan (Dewi et al., 2018).

Bila melihat laporan keuangan beberapa hari terakhir yang sudah dirilis secara keseluruhan, kinerja keuangan perusahaan food and beverage pada kuartal I tahun ini cukup baik. Ind ustri makanan dan minuman menjadi salah satu sektor manufaktur andalan dalam memberikan kontribusi besar terhadap pertumbuhan ekonomi nasional. Capaian kinerja di perusahaan food and beverage selama ini tercatat konsisten terus positif, mulai dari perannya terhadap peningkatan produktivitas, investasi, ekspor hingga penyerapan tenaga kerja (Kementrian Perindustrian Republik Indonesia, 2019).

Industri food and beverage menjadi salah satu sektor manufaktur andalan dalam memberikan kontribusi besar terhadap pertumbuhan ekonomi nasional. Pada triwulan I 2015, pertumbuhan food and beverage mencapai 8,16\%. Tahun 2016 triwulani III memberikan kontribusi 33,6\%. Kemudian tahun 2017 triwulan III, kinerjanya naik sebesar 9,49\%. Triwulani III tahun 2018 mencapai 8,67\%. Hingga triwulani I 2019, pertumbuhan PDB industri makanan dan minuman mencapai $6,77 \%$. Angka itu di atas pertumbuhan PDB industri nasional sebesar 5,07\%. Sektor tersebut pun berkontribusi sebesar 35,58\% terhadap PDB Industri Non Migas dan sebesar 6,35\% terhadap PDB Nasional (Kementrian Perindustrian Republik Indonesia). 
Penelitian yang dilakukan di Vietnam, hasil penelitian menunjukkan bahwa kepemilikan manajerial berpengaruh positif signifikan terhadap kinerja keuangan (Quang \& Xin 2014). Sejalan dengan penelitian di Malaysia kepemilikan manajerial berpengaruh positif signifikan terhadap kinerja keuangan (Amran \& Ahmad, 2013). Besar kecilnya jumlah kepemilikan saham manajerial dalam perusahaan dapat mengindikasikan adanya kesamaan kepentingan antara manajemen dengan stakeholder. Semakin besar kepemilikan saham oleh manajer, maka semakin produtif tindakan manajer dalam memaksimalkan kinerja perusahaan.

Hasil penelitian ini berbeda di Nigeria yang menunjukkan hasil kepemilikan manajerial tidak berpengaruh terhadap kinerja keuangan (Saidu \& Gidado, 2018). Sejalan dengan penelitian kepemilikan manajerial berpengaruh negatif signifikan dengan kinerja keuangan perusahaan karachi Rehman et al., (2012) dan di perusahaan Malaysia (Jusoh et al.,, 2013). Belum banyak pihak manajemen yang memiliki saham perusahaan dengan jumlah cukup signifikan. Jumlah kepemilikan manajerial rendah menyebabkan pihak manajemen lebih mementingkan kepentingan sendiri daripada perusahaan.

Penelitian di negara Mesir mengemukakan bahwa kepemilikan institusional berpengaruh positif terhadap kinerja keuangan (Masry, 2016). Hasil penelitian sejalan dengan penelitian di Indonesia, bahwa kepemilikan institusional berpengaruh positif terhadap kinerja keuangan perusahaan (Nurlaela et al., 2016). Kepemilikan saham institusional tinggi oleh pihak institusi akan meningkatkan pengawasan terhadap perusahaan untuk meminimalisir tingkat penyelewengan yang dilakukan oleh pihak manajemen. Pemilik institusional akan berusaha melakukan usaha-usaha positif guna meningkatkan kinerja keuangan perusahaan.

Penelitian dengan hasil berbeda ditemukan dinegara Indonesia, yang menemukan bahwa kepemilikan institusional kepemilikan institusional berpengaruh negatif terhadap kinerja keuangan yang diukur dengan ROA (Wiranata \& Yeterina, 2013) dan (Rifqi, 2013). Semakin tinggi kepemilikan institusional maka semakin rendah kinerja keuangan, dikarenakan kepemilikan institusional adalah pemilik sementara dan lebih memfokuskan laba jangka pendek.

Penelitian yang dilakukan di Pakistan, menunjukkan hasil bahwa dewan komisaris independen berpengaruh positif terhadap kinerja keuangan bank yang terdaftar di bursa Karachi (Gull et al., 2013). Sejalan dengan penelitian di Indonesia dewan komisaris independen berpengaruh positif terhadap kinerja keuangan (Widyati, 2013). Dewan komisaris independen bertindak sebagai wakil dari stakeholder untuk mengawasi jalannya kegiatan perusahaan. Dewan komisaris independen memberikan dampak positif pada perusahaan karena memberikan masukan solutif dan inovatif untuk memecahkan masalah sehingga mampu meningkatkan kinerja perusahaan.

Berbeda ditahun sebelumnya di Nigreria, menunjukkan bahwa dewan komisaris independen tidak berpengaruh terhadap kinerja keuangan (Nuhu et al., 2017). Hasil serupa terjadi pada penelitian di negara Banglades yang menyatakan dewan komisaris independen tidak berpengaruh terhadap kinerja keuangan (Kutubi, 2011). Hal ini mengindikasikan bahwa adanya dewan 
komisaris independen dalam perusahaan dinilai belum mampu memberikan dampak yang baik terutama dalam tugasnya untuk melakukan pemantauan atau pengawasan terhadap manajer perusahaan sehingga para pelaku pasar belum sepenuhnya mempercayai kinerja komisaris independen dalam perusahaan.

Penelitian di Indonesia menunjukan bahwa ukuran komite audit berpengaruh terhadap kinerja keuangan (Sekaredi \& Adiwibowo, 2011).Dengan semakin banyaknya anggota komite audit, maka dapat meningkatkan efektivitas komite audit sehingga dapat mencegah praktik manajemen laba yang dilakukan manajemen. Efektifnya fungsi pengawasan juga dapat meningkatkan kinerja keuangan perusahaan.

Berbeda dengan hasil yang mengatakan komite audit tidak berpengaruh terhadap kinerja keuangan (Mulyadi et al., 2019) dan (Alvilika et al., 2019). Bahwa tinggi rendahnya jumlah komite audit tidak mempengaruhi peningkatan atau penurunan kinerja keuangan perusahaan yang diproksikan dengan ROA. Keberadaan komite audit tidak bisa menjamin kualitas laporan keuangan, fungsi pengawasan dan pengendalian pada manajemen perusahaan sehingga tidak berpengaruh terhadap kinerja keuangan perusahaan.

Berdasarkan latar belakang yang diuraikan sebelumnya, maka penulis merumuskan masalah dalam penelitian ini sebagai berikut: Apakah kepemilikan manajerial, kepemilikan institusional, dewan komisaris independen, dan komite auditberpengaruh terhadap kinerja keuangan? Tujuan penelitian ini yaitu : Untuk menganalisa pengaruh kepemilikan manajerial, kepemilikan institusional, dewan komisaris independen, dan komite audit terhadap kinerja keuangan.

Teori stakeholder merupakan teori yang menyatakan bahwa perusahaan bukanlah entitas yang hanya beroperasi untuk kepentingan sendiri, namun harus memberikan manfaat kepada seluruh stakeholder perusahaan (Imam \& Chariri, 2007). Stakeholder merupakan semua pihak baik internal (manajer, dewan komisaris independen, komite audit) atau eksternal (institusi) yang memiliki pengaruh untuk perusahaan. Tujuan teori stakeholder membantu manajemen perusahaan dalam meningkatkan penciptaan nilai sebagai dampak dari aktivitas yang dilakukan agar dapat meningkatkan kinerja keuangan perusahaan.

Dalam meneliti kinerja keuangan perusahaan ini sangat erat hubungannya dengan Stakeholder theory, karena tidak hanya pihak manajemen perusahaan saja tetapi pemegang saham, kreditor, konsumen, supplier, pemerintah, masyarakat, analis, dan pihak lain juga perlu untuk mengetahui bagaimana perkembangan atau kondisi keuangan sebuah perusahaan. Untuk meningkatkan kinerja keuangan perusahaan, maka pihak internal dan eksternal perlu bekerja sama. Untuk mengukur kinerja perusahaan dalam penelitian ini adalah Return On Asset (ROA) yaitu perbandingan laba bersih dengan jumlah aktiva perusahaan.

Kepemilikan Manajerial merupakan pemilik saham perusahaan yang berasal dari manajemen yang ikut serta dalam pengambilan keputusan suatu perusahaan yang bersangkutan. Dalam stakeholder theory, hubungan pemegang saham dan manajer sama-sama kuat, karena disini manajer selain bertanggung jawab sebagai manajemen perusahaan, ia juga berperan sebagai pemegang saham. Kepemilikan saham oleh manajemen akan mensejajarkan kedudukan manajer dengan stakeholder. Kepemilikan manajerial menjadi salah satu faktor 
yang dapat mempengaruhi kinerja perusahaan. Semakin meningkatnya proporsi kepemilikan manajerial maka akan semakin baik kinerja perusahaan sehingga manajer akan termotivasi untuk meningkatkan kinerjanya untuk perusahaan.

Penelitian yang dilakukan Kumai et al., (2014) mengemukakan bahwa kepemilikan manajerial berpengaruh positif dan signifikan terhadap kinerja keuangan (ROA). Pihak manajemen yang memiliki saham dalam perusahaan cenderung menyusun strategi untuk meningkatkan kinerja perusahaan. Penelitian yang dilakukan oleh Ongore \& Owoko (2011), Noviawan \& Septiani (2013) dan Candradewi \& Sedana (2016) menunjukan hasil bahwa kepemilikan manajerial berpengaruh positif signifikan terhadap kinerja keuangan perusahaan. Hasil ini mendukung pernyataan bahwa dengan kepemilikan manajerial dapat mendorong untuk bertindak sesuai dengan kepentingan pemegang saham dan dapat meningkatkan kinerja perusahaan. Hal ini menunjukkan proporsi saham yang dikendalikan oleh manajer dapat mempengaruhi kebijakan perusahaan. Kepemilikan saham manajerial yang tinggi akan mendorong manajemen melakukan fungsinya dengan baik, karena hal tersebut bertujuan untuk meningkatkan kesejahteraan pemegang saham dan untuk kepentingannya sendiri.

$\mathrm{H}_{1}$ : Kepemilikan Manajerial Berpengaruh Positif Signifikan Terhadap Kinerja Perusahaan.

Kepemilikan Institusional merupakan proporsi kepemilikan saham oleh institusi pendiri perushaan, bukan institusi pemegang saham publik yang diukur dengan presentase jumlah saham yang dimiliki oleh investor institusi intern (Sujoko, 2007). Dalam kepemilikan institusional ini, stakeholder juga bertanggung jawab atas kemajuan perusahaan itu. Keberadaan investor institusional mampu menjadi mekanisme monitoring efektif dalam setiap keputusan yang diambil oleh manajer. Penerapan kepemilikan insitusional mampu meningkatkan kinerja perusahaan.

Sesuai penelitian yang dilakukan Candradewi \& Sedana (2016) menunjukkan bahwa kepemilikan institusional berpengaruh positif signifikan terhadap kinerja keuangan (ROA). Sejalan dengan penelitian yang dilakukan oleh Kumai et al., (2014) dan Noviawan \& Septiani (2013) menunjukkan bahwa kepemilikan institusional berpengaruh positif signifikan terhadap kinerja keuangan (ROA). Adanya investor institusional pada suatu perusahaan dipercaya dapat meningkatkan kinerja perusahaan. Semakin besar kepemilikan oleh institusi maka akan semakin besar kekuatan suara dan dorongan institusi untuk mengawasi manajemen dan akibatnya akan memberikan dorongan yang lebih besar untuk mengoptimalkan nilai perusahaan sehingga kinerja perusahaan juga akan meningkat.

$\mathrm{H}_{2}$ : Kepemilikan Institusional Berpengaruh Positif Signifikan Terhadap Kinerja Perusahaan.

Dewan komisaris independen berperan penting bagi perusahaan, karena dapat mencegah adanya tindak manejemen yang tidak transparan. Adanya dewan komisaris independen maka kepentingan stakeholder, baik mayoritas maupun minoritas tidak diabaikan karena komisaris independen lebih bersikap netral terhadap keputusan yang dibuat oleh manajer. Dewan komisaris independen sangat menentukan keberhasilan perusahaan dalam mencapai 
tujuan dan meningkatkan kinerja keuangan perusahaan, sehingga dapat meminimalkan kerugian yang mungkin akan muncul. Selain itu dapat membantu perusahaan menghindari ancaman-ancaman dari luar, sehingga perusahaan mendapatkan keuntungan yang lebih, yang nantinya dapat meningkatkan kinerja keuangan.

Sesuai penelitian yang dilakukan oleh Latief et al., (2014) menunjukkan bahwa dewan komisaris independen berpengaruh positif dan signifikan terhadap kinerja keuangan yang diukur dengan ROA. Penetilian itu sama dengan hasil penelitian yang dilakukan oleh Widyati (2013) dan Arosa et al., (2012) dewan komisaris independen berpengaruh positif signifikan terhadap kinerja keuangan. Hal ini mendukung pernyataan bahwa dewan komisaris independen dapat meningkatkan kinerja perusahaan. Dewan komisaris independen diharapkan bisa meningkatkan pengawasan dalam menciptakan lingkungan usaha yang sesuai dengan tata kelola perushaan yang baik.

$\mathrm{H}_{3}$ : Dewan Komisaris Independen Berpengaruh Positif Signifikan Terhadap Kinerja Perusahaan.

Komite audit merupakan salah satu bagian dari stakeholder, karena komite bertanggung jawab kepada dewan komisaris untuk membantu melaksanakan tugas dewan komisaris, maka dengan semakin banyaknya anggota komite audit pengawasan yang berkaitan dengan keuangan dan prosedur akuntansi, sehingga kinerja perusahaan semakin meningkat. Secara spesifik, komite audit membantu dewan komisaris dari sisi pengawasan dan bertanggung jawab menjaga akses komunikasi antar stakeholder. Keberadaan Komite Audit yang professional dan independen dalam suatu perusahaan menjadi syarat mutlak untuk menjaga kepentingan stakeholders dan melindungi hak-hak pemegang saham.

Penelitian yang dilakukan oleh Hermiyetti \& Katlanis (2017) mengatakan bahwa komite audit berpengaruh positif signifikan terhadap kinerja keuangan. Penelitian tersebut didukung oleh Sekaredi \& Adiwibowo (2011) yang menyatakan bahwa komite audit berpengaruh positif signifikan terhadap kinerja keuangan. Hal tersebut mendukung pernyatan komite audit meningkatkan kinerja perusahaan. Semakin banyak jumlah komite audit yang dimiliki oleh suatu perusahaan akan memberikan perlindungan dan kontrol yang lebih baik terhadap proses akuntansi dan keuangan dan pada akhirnya akan memberikan pengaruh positif terhadap kinerja keuangan.

$\mathrm{H}_{4}$ : Komite Audit Berpengaruh Positif Signifikan Terhadap Kinerja Perusahaan.

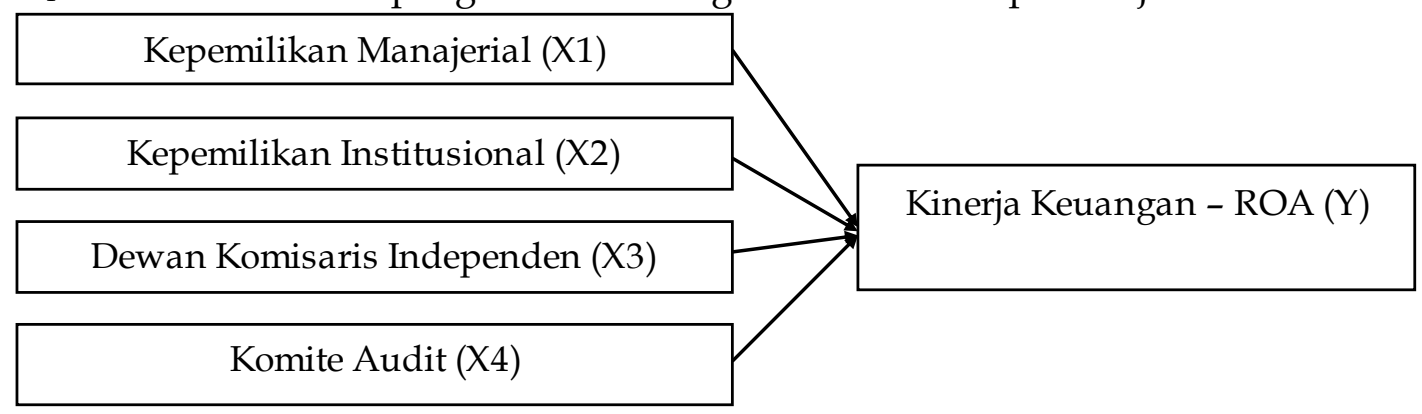

Gambar 1. Kerangka Konsep Penelitian

Sumber: Data Penelitian, 2019 
Pada gambar menunjukkan bahwa Kinerja Keuangan (Y) sebagai variabel dependen yang dipengaruhi variabel independen yaitu Kepemilikan Manajerial (X1), Kepemilikan Institusional (X2), Dewan Komisaris Independen (X3), Komite Audit (X4). Dengan adanya kerangka penelitian ini digunakan untuk mempermudah jalan pemikiran terhadap masalah yang akan dibahas.

\section{METODE PENELITIAN}

Jenis penelitian yang dilakukan adalah penelitian kuantitatif. Dalam penelitian ini terdapat dua variabel yang digunakan diantaranya adalah variabel dependen (kinerja keuangan) dan variabel independen (kepemilikan manajerial, institusional, dewan komisaris independen, komite audit). Berikut ini adalah pengukuran masing-masing variabel yang diajukan dalam penelitian ini terdiri dari:

Kepemilikan manajerial, dalam laporan keuangan, keadaan ini dapat dilihat dari besarnya persentase kepemilikan saham perusahaan oleh manajer. Rumusnya diformulasikan sebagai berikut (Rachmad, 2013) :

$K e p_{M n j}=\frac{\text { Jumlah Saham Manajerial }}{\text { Total Saham Beredar }} \times 100 \%$

Kepemilikan institusional dalam laporan keuangan, keadaan ini dapat dilihat dari besarnya persentase kepemilikan saham perusahaan oleh investor institusi intern. Rumusnya diformulasikan sebagai berikut (Rachmad, 2013) :

$$
\begin{aligned}
& \mathrm{Kep}_{\text {Ins }}= \\
& \frac{\text { Jumlah Saham Institusional }}{\text { Total Saham Beredar }} \times 100
\end{aligned}
$$

Dewan komisaris independen dalam laporan keuangan, keadaan ini dapat dilihat dari struktur manajemen perusahaan, pada jumlah dewan komisaris independen. Rumusnya dapat diformulasikan sebagai berikut (Rachmad, 2013) :

$D K I=\frac{\text { Jumlah Anggota Dewan Komisaris }}{\text { Jumlah Komisaris Independen }} \times 100 \%$

Komite audit dalam laporan keuangan, keadaan ini dapat dilihat dari struktur manajemen perusahaan bagian komite audit. Pengukuran komite audit dalam penelitian ini yaitu dengan menggunakan proporsi komite audit, yaitu perbandingan jumlah komite audit dengan jumlah dewan komisaris seperti yang dilakukan (Sulistya, 2013) :

Kom_Aud $=\frac{\text { Jumlah Komite Audit }}{\text { Jumlah Dewan Komisaris }}$.

Kinerja keuangan pada penelitian ini diukur dengan menggunakan raiso roa, merupakan rasio yang digunakan untuk mengukur kemampuan manajemen perusahaan dalam memperoleh laba (keuntungan) secara keseluruhan. Rumusnya dapat diformulasikan sebagai berikut ( Hanafi, 2009) :

$R O A=\frac{\text { Laba Bersih Setelah Pajak }}{\text { Total Asset }} \times 100 \%$.

Sumber data yang digunakan dalam penelitian ini adalah data sekunder. Data yang dibutuhkan terdapat dalam annual report atau laporan keuangan auditan perusahaan sektor food and beverage selama periode 2014-2018 yangi terdaftar di Bursa Efek Indonesia atau www.idx.co.id dan situs resmi masingmasing perusahaan. Populasi dan sampel yang digunakan dalam penelitian ini adalah seluruh perusahaan food and beverage yang terdaftar di BEI periode 
2014-2018 sejumlah 13 perusahaan. Teknik pengambilan sampel dalam penelitian ini menggunakan purposive sampling merupakan teknik pemilihan sampel dapat memberikan informasi yang dibutuhkan dalam penelitian berdasarkan kriteria tertentu sesuai dengan tujuan penelitian (Sugiyono, 2014).

Metode analisis data menggunakan Regresi Linier Berganda (uji $t$, uji $f$, dan uji koefisien determinasidengan uji asumsi klasik yang meliputi uji normalitas, uji multikolinearitas, uji autokorelasi, uji heteroskedasitas untuk memeriksa perbedaan mutlak. Model Regresi linier berganda dalam penelitian ini, dinyatakan dengan persamaan sebagai berikut :

$Y=\alpha+\beta 1 . \mathrm{X} 1+\beta 2 . \mathrm{X} 2+\beta 3 . \mathrm{X} 3+\beta 3 . \mathrm{X} 4+\varepsilon$

Keterangan:

$\mathrm{Y} \quad=$ Kinerja Keuangan Perusahaan

a $\quad=$ Konstanta

$\beta 1, \beta 2, \beta 3, \beta 4=$ Koefisien regresi

$\mathrm{X}_{1} \quad=$ Kepemilikan Manajerial

$\mathrm{X}_{2} \quad=$ Kepemilikan Institusional

$\mathrm{X}_{3} \quad=$ Dewan Komisaris Independen

$\mathrm{X}_{4} \quad=$ Komite Audit

$\varepsilon \quad=$ Error

\section{HASIL DAN PEMBAHASAN}

Sumber data skunder yang digunakna dalam penelitian ini merupakan data skunder yang merupakan laoran keuangan perusahaan yang terdaftar di BEI dalam sektor food and beverage periode 2014 - 2018. Kriteria yang disebutkan yaitu:

Tabel 1. Prosedur Pengambilan Sampel

\begin{tabular}{lc}
\hline \multicolumn{1}{c}{ Kriteria } & Jumlah \\
\hline $\begin{array}{l}\text { Perusahaan food and beverage yang terdaftar di Bursa Efek Indonesia (BEI) } \\
\text { tahun 2014-2018. }\end{array}$ & 26 \\
$\begin{array}{l}\text { Perusahaan yang tidak menerbitkan laporan keuangan danlaporan tahunan } \\
\text { secara lengkap untuk periode 2014-2018 / Tidak memiliki kelengkapan }\end{array}$ & $(9)$ \\
informasi yang dibutuhkan dalam keperluan penelitian. & \\
Perusahaan food and beverage yang mengalami kerugian selama periode & $(4)$ \\
2014-2018. & 13 \\
Total sampel perusahaan & 65 \\
Total sampel pengamatan & \\
\hline
\end{tabular}

Sumber: Data Penelitian, 2019

Tabel 1, menyajikan data Perusahaan food and beverage yang terdaftar di Bursa Efek Indonesia (BEI) tahun 2014-2018 yaitu sebesar 26 perusahaan dengan jumlah perusahaan uang tidak menerbitkan laporan keuangan dan laporan tahunan secara lengkap pada periode 2014-2018 sebesar 9 perusahaan dan perusahaan pada sector food and beverage yang mengalami kerugian selama periode 2014 - 2018 sebesar 4 perusahaan. Berdasarkan data yang didapat pada Tabel 1, total sampel peperusahaan yaitu 13 perusahaan dengan total sampel pengamatan sebesar 65 perusahaan.

Perusahaan sektor food and beverage yang terdaftar di Bursa Efek Indonesia tahun 2014-2018 merupakan populasi yang akan digunakan dalam 
penelitian ini. Teknik sampling yang digunakan dalam penelitian ini yaitu dengan cara purposive sampling, sehingga terpilih 13 perusahaan. Seluruh perusahaan yang termasuk didalamnya disajikan pada Tabel 2.

Tabel 2. Daftar Perusahaan Sektor Food And Beverage

\begin{tabular}{lll}
\hline No & Kode Emiten & Nama Perusahaan \\
\hline 1. & ADES & Akasha Wira International Tbk \\
2. & BUDI & Budi Starch \& Sweetener Tbk \\
3. & CEKA & Wilmar Cahaya Indonesia Tbk \\
4. & DLTA & Delta Djakarta Tbk \\
5. & ICBP & Indofood CBP Sukses Makmu Tbk \\
6. & INDF & Indofood Sukses Makmur Tbk \\
7. & MLBI & Multi Bintang Indonesia Tbk \\
8. & MYOR & Mayora Indah Tbk \\
9. & ROTI & Nippon Indosari Corpindo Tbk \\
10. & SKBM & Sekar Bumi Tbk \\
11. & SKLT & Sekar Laut Tbk \\
12. & STTP & Siantar Top Tbk \\
13. & ULTJ & Ultra Jaya Milk Industry \& Tranding Company Tbk \\
\hline
\end{tabular}

Sumber: www.idx.co.id, 2019

Hasil uji tabel 3 menunjukkan bahwa Variabel Kepemilikan Manajerial yang diukur dengan proporsi saham yang dimiliki oleh jajaran manajemen perusahaan menunjukkan nilai rata-rata 0.0943 atau 9.4\%. Rata-rata tersebut menunjukkan bahwa ada manajer yang sekaligus juga pemilik saham di perusahaan. Kepemilikan Institusional menunjukkan proporsi saham perusahaan yang dimiliki oleh pihak luar perusahaan. Rata-rata kepemilikan saham institusi diperoleh sebesar 0.0789 atau $71 \%$. Kepemilikan saham oleh institusi diharapkan dapat menjadi penekan pada kebijakan manajerial. Dewan Komisaris Independen dewan komisaris yang tidak terafiliasi dengan manajemen. Rata-rata dewan komisaris independen sebesar 0.3654 atau 36\%. Dewan komisaris independen diharapkan dapat meningkatkan pengawasan dan dapat mencegah adanya tindak manajemen yang tidak transparan. Komite Audit bertanggung jawab kepada dewan komisaris untuk membantu melaksanakan tugas dewan komisaris. Rata-rata komite audit 0.8265 atau $83 \%$. Komite Audit diharapkan dapat membantu dewan komisaris dalam memastikan efektivitas sistem pengendalian internal dan efektivitas pelaksanaan tugas auditor eksternal dan internal. Variabel ROA ialah ukuran kinerja keuangan perusahaan, yang menunjukkan rata-rata 0.0768 atau $7.6 \%$. Rata-rata tersebut menunjukkan bahwa perusahaan belum efektif dalam memanfaatkan aktiva untuk menghasilkan keuntungan. Nilai ROA minimum $2 \%$, sedangkan maksimumnya $17 \%$.

Tabel 3. Hasil dari Uji Statistik Deskriptif

\begin{tabular}{llllll}
\hline Variabel & $\mathrm{N}$ & Min & Max & Mean & Dev. Std \\
\hline Kepemilikan Manajerial & 65 & 0.00 & 0,35 & 0,0943 & 0,08233 \\
Kepemilikan Institusional & 65 & 0,33 & 1,00 & 0,7089 & 0,18779 \\
$\begin{array}{l}\text { Dewan Komisaris } \\
\text { Independen }\end{array}$ & & & & & \\
Komite Audit & 65 & 0,33 & 0,50 & 0,3654 & 0,05818 \\
ROA & 65 & 0,75 & 3,00 & 0,8265 & 0,25010 \\
Valid N (listwise) & 65 & 0,02 & 0,17 & 0,0768 & 0,03989 \\
\hline
\end{tabular}

Sumber: Data Penelitian, 2019 
Tabel 4. Hasil dari Uji One-Sample Kolmogorov-Smirnov Test

\begin{tabular}{llll}
\hline $\mathrm{N}$ & Asym Sig & Standar & Keterangan \\
\hline 65 & 0,935 & $>0,05$ & Data Normal \\
\hline
\end{tabular}

Sumber: Data Penelitian, 2019

Hasil uji Tabel 4, menunjukkan bahwa nilai signifikasi 0,935 lebih besar dari standar 0,05 $(0,935>0,05)$ yang berarti bahwa data penelitian ini berdistribusi normal.

Tabel 5. Hasil dari Uji Multikolinearitas

\begin{tabular}{|c|c|c|c|c|c|}
\hline Variabel Independen & Tolerance & $\overline{\text { Std }}$ & VIF & Std & Ket \\
\hline Kepemilikan & 0,676 & $>0,10$ & 1,480 & $<10$ & Terjadi \\
\hline Manajerial & & & & & Multikolinearitas \\
\hline Kepemilikan & 0,648 & $>0,10$ & 1,544 & $<10$ & Tdk $\quad$ Terjadi \\
\hline Institusional & & & & & Multikolinearitas \\
\hline Dewan Komisaris & 0,243 & $>0,10$ & 4,120 & $<10$ & Tdk $\quad$ Terjadi \\
\hline Independen & & & & & Multikolinearitas \\
\hline Komite Audit & 0,227 & $>0,10$ & 4,399 & $<10$ & $\begin{array}{l}\text { Tdk Terjadi } \\
\text { Multikolinearitas }\end{array}$ \\
\hline
\end{tabular}

Sumber: Data Penelitian, 2019

Hasil uji Tabel 5, mengidenfikasikan bahwa variabel kepemilikan manajerial mempunyai nilai Tolerance $0.676>0,10$ dan VIF $1.480<10$. Berarti kepemilikan manajerial tidak terjadi multikolinearitasi. Variabel kepemilikan institusional mempunyai nilai Tolerance $0.648>0,10$ dan VIF $1.544<10$, berarti tidak terjadi multikolinearitasi. Berarti kepemilikan institusional tidak terjadi multikolinearitasi. Variabel dewan komisaris independen mempunyai nilai Tolerance $0.243>0,10$ dan VIF $4.120<10$, berarti tidak terjadi multikolinearitasi. Berarti dewan komisaris independen tidak terjadi multikolinearitasi. Variabel komite audit mempunyai nilai Tolerance $0.227>0,10$ dan VIF $4.399<10$, berarti tidak terjadi multikolinearitasi. Berarti komite audit tidak terjadi multikolinearitasi.

Tabel 6. Hasil dari Uji Autokorelasi

\begin{tabular}{cccc}
\hline $\mathrm{N}$ & Asym Sig & Standar & Keterangan \\
\hline 65 & 0,902 & $>0,05$ & tidak terjadi autokorelasi
\end{tabular}

Sumber: Data Penelitian, 2019

Hasil uji Tabel 6, menunjukkan bahwa responden 65 menghasilkan nilai Asymp. Sig. (2-tailed) sebesar 0,902 lebih besar dari nilai standar 0,05 (0,902 > $0,05)$. Maka dapat disimpulkan bahwa data regresi tidak terjadi autokorelasi.

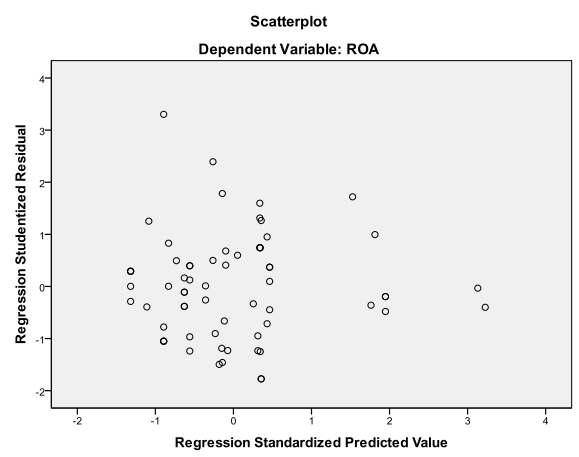

Gambar 2. Hasil dari Uji Heteroskedastisitas

Sumber: Data Penelitian, 2019 
Hasil uji Tabel 7, grafik scatterplot dari variabel dependen yaitu kinerja perusahaan. Grafik scatterplot tersebut dapat dilihat bahwa titik data tersebar di atas dan di bawah atau angka 0 sumbu $Y$, penyebaran titik-titik data tidak membentuk pola bergelombang melebar kemudian menyempit dan melebar kembali. Hal ini bisa disimpulkan bahwa tidak terjadi heteroskedastisitas pada model regresi, sehingga model regresi layak dipakai untuk memprediksi variabel dependen berdasarkan masukan variabel independennya.

Persamaan dari regresi linier berganda yang digunakan dalam penelitian ini adalah:

Tabel 8. Hasil Uji Regresi Linier Berganda

\begin{tabular}{llrrrrc}
\hline \multirow{2}{*}{ Model } & \multicolumn{2}{c}{$\begin{array}{c}\text { Unstandardized } \\
\text { Coefficients }\end{array}$} & $\begin{array}{c}\text { Standardized } \\
\text { Coefficients }\end{array}$ & \\
\cline { 2 - 6 } & & $\mathrm{B}$ & Std. Error & Beta & $\mathrm{T}$ & Sig. \\
\hline 1 & (Constant) & $-0,082$ & 0,082 & & $-1,000$ & 0,322 \\
& Kepemilikan Manajerial & 0,143 & 0,669 & 0,282 & 2,062 & 0,044 \\
& Kepemilikan Institusional & $-0,051$ & 0,031 & $-0,233$ & $-1,667$ & 0,101 \\
Dewan Komisaris & 0,332 & 0,164 & 0,463 & 2,027 & 0,047 \\
Independen & & & & & \\
Komite Audit & 0,085 & 0,039 & 0,507 & 2,149 & 0,036 \\
RSquere & & & & & 0,241 \\
F Statistik & & & & & 4,768 \\
SignifikansiUji F & & & & & 0,002 \\
\hline
\end{tabular}

Sumber: Data Penelitian, 2019

Dari Tabel 8, dapat ditentukan persamaan regresinya berdasarkan kolom B yang merupakan koefisien regresi tiap variabelnya. Jadi persamaan regresinya adalah sebagai berikut:

$$
Y=-0,082+0,143 X_{1}-0,051 X_{2}+0,332 X_{3}+0,085 X_{4}
$$

Nilai constant sebesar -0.082 , maka variabel independen dianggap konstan atau bernilai 0 , maka nilai tetap -0.082. Koefisien regresi kepemilikan manajerial senilai 0.143 , artinya apabila variabel kepemilikan manajerial dinaikkan sebesar 1 , nilai ROA meningkat senilai 0.143 . Koefisien regresi kepemilikan institusional senilai -0.051, artinya apabila variabel kepemilikan institusional dinaikkan sebesar 1 , nilai ROA menurun senilai -0.051. Koefisien regresi dewan komisaris independen senilai 0.332 , artinya apabila variabel dewan komisaris independen dinaikkan sebesar 1 , nilai ROA meningkat senilai 0.332 . Koefisien regresi komite audit senilai 0.085 , artinya apabila variabel komite audit dinaikkan sebesar 1 , nilai ROA meningkat senilai 0.085 .

Hasil uji F diatas, diperoleh Fhitung $4.768>$ Ftabel 2.550 dan signifikansi $0.002<0.05$. Dapat diartikan bahwa secara simultan variabel independen berpengaruh signifikan terhadap variabel dependen, ini berarti model yang digunakan pada penelitian ini adalah layak. Hal ini berarti model dapat digunakan untuk analisis lebih lanjut.

Hasil Uji $t$, hipotesis Kepemilikan manajerial diterima sehingga kepemilikan manajerial nilai thitung $>\mathrm{t}$ tabel $(2,062>1,985)$ dan signifikan sebesar 0,044<0,05 artinya hipotesis diterima, sehingga kepemilikan manajerial berpengaruh terhadap kinerja keuangan perusahaan. Kepemilikan manajerial berpengaruh positif signifikan terhadap kinerja keuangan perusahaan. Pihak 
manajemen yang memiliki saham dalam perusahaan cenderung menyusun strategi untuk meningkatkan kinerja perusahaan. Penelitian tersebut didukung oleh penelitian Ongore \& Owoko (2011) dan Noviawan \& Septiani (2013) menyatakan bahwa kepemilikan manajerial memiliki pengaruh yang positif signifikan terhadap kinerja perusahaan ROA. Besar kecilnya jumlah kepemilikan saham manajerial dalam perusahaan dapat mengindikasikan adanya kesamaan kepentingan antara manajemen dengan stakeholder.

Hipotesis kepemilikan institusional nilai thitung $>\mathrm{t}$ tabel $(-1,667<1,985)$ dan signifikan sebesar 0,101 $>0,05$ artinya hipotesis ditolak, sehingga kepemilikan institutional tidak berpengaruh terhadap kinerja keuangan perusahaan. Kepemilikan institusional berpengaruh negatif signifikan terhadap kinerja keuangan. Artinya kepemilikan jumlah saham yang tinggi oleh institusi ini menyebabkan pihak institusi bertindak untuk kepentingan mereka sendiri dengan mengorbankan kepentingan pemegang saham minoritas dan akan membuat terjadinya ketidakseimbangan dalam penentuan arah kebijakan perusahaan yang nantinya menyebabkan keadaan tindak kondusif dan tidak akan meningkatkan kinerja keuangan. Penjelasan tersebut didukung dengan penelitian Fadillah (2017), Suhardjanto \& Ajibroto (2017), dan Rifqi (2013) menunjukkan bahwa, kepemilikan institusional berpengaruh negatif signifikan terhadap kinerja keuangan yang diukur dengan ROA. Semakin tinggi kepemilikan institusional maka semakin rendah kinerja keuangan, dikarenakan kepemilikan institusional adalah pemilik sementara dan lebih memfokuskan laba jangka pendek.

Hipotesis dewan komisaris independen nilai thitung $>t$ tabel $(2,027>$ $1,985)$ dan signifikan sebesar 0,047 < 0,05 artinya hipotesis diterima, sehingga dewan komisaris independen berpengaruh terhadap kinerja keuangan perusahaan. Dewan komisaris independen berpengaruh positif signifikan terhadap kinerja keuangan. Dengan adanya proporsi dewan komisaris independen yang tinggi maka kinerja keuangan perusahaan akan meningkat. Semakin tinggi proporsi untuk dewan komisaris independen maka komisaris independen akan memberikan sanksi yang tegas terhadap pekerja yang mengalami penurunan kinerja. Penelitian tersebut didukung dengan penelitian yang dilakukan Latief et al., (2014) dan Nurlaela et al., (2017) menunjukkan bahwa terdapat pengaruh positif dan signifikan antara dewan komisaris independen terhadap kinerja keuangan yang diukur dengan ROA. Dewan komisaris independen sangat menentukan keberhasilan perusahaan dalam mencapai tujuan dan meningkatkan kinerja keuangan perusahaan.

Hipotesis komite audit nilai thitung $>\mathrm{t}$ tabel $(2,149>1,985)$ dan signifikan sebesar 0,036 < 0,05 artinya hipotesis diterima, sehingga komite audit berpengaruh terhadap kinerja keuangan perusahaan. Komite audit berpengaruh positif signifikan terhadap kinerja keuangan. Keberadaan komite audit akan memastikan bahwa perusahaan akan menerapkan prinsip-prinsip akuntansi yang akan menghasilkan informasi keuangan yang akurat dan berkualitas. Penelitian tersebut didukung dengan penelitian Arifani (2012) dan Hermiyetti \& Katlanis (2017) yang membuktikkan bahwa komite audit, berpengaruh positif signifikan terhadap kinerja keuangan. Dengan demikian maka semakin banyak 
jumlah komite audit akan mempengaruhi kinerja internal perusahaan sehingga akan membuat kinerja keuangan perusahaan menjadi lebih baik.

Hasil uji Uji koefisien determinasi (R2) menunjukkan nilai dari Adjusted $\mathrm{R}$ Square senilai 0,241 yang berarti variabel independen mempunyai pengaruh terhadap variabel dependen sebesar $24 \%$. Sisanya $76 \%$ dipengaruhi oleh variabel lain, seperti dewan komisaris, ukuran perusahaan, kualitas audit, dan sebagainya.

\section{SIMPULAN}

Kesimpulannya kepemilikan manajerial, kepemilikan institusional, dewan komisaris independen, dan komite audit secara simultan berpengaruh positif signifikan terhadap kinerja keuangan perusahaan (ROA). Secara parsial kepemilikan manajerial, dewan komisaris independen, komite audit berpengaruh positif signifikan terhadap kinerja perusahaan (ROA). Sedangkan kepemilikan institusional tidak berpengaruh terhadap kinerja keuangan (ROA). Kepemilikan saham oleh menejemen, dapat meningkatkan kinerja keuangan perusahaan. Semakin besar proporsi dewan komisaris independen dan komite audit maka pengawasan yang dilakukan semakin baik, sehingga kinerja keuangan perusahaan pun semakin meningkat. Kemudian kepemilikan institusional tidak memiliki dampak terhadap kinerja keuangan perusahaan. Tinggi rendahnya kepemilikan saham oleh intern tidak menjadi tolak ukur bahwa kepemilikan institusional berdampak pada kinerja keuangan perusahaan.

Penelitian terbatas pada perusahaan food and beverage dengan periode penelitian 5 tahun berturut-turut yaitu mulai tahun 2014 sampai dengan 2018 sehingga hasil penelitian tidak dapat digeneralisasikan di perusahaan sektor lain. Komponen variabel independen yang digunakan dalam penelitian ini kepemilikan manajerial, kepemilikan institusional, dewan komisaris independen, dan komite audit hanya mampu memberi pengaruh terhadap kinerja perusahaan sebesar $24 \%$, sedangkan $76 \%$ dipengaruhi oleh variabel lain.

Untuk penelitian selanjutnya, variabel independen dapat ditambah lagi (misalkan : dewan komisaris, dewan direksi, kualitas audit, ukuran perusahaan, dan lain-lain), guna meningkatkan pengaruh terhadap kinerja keuangan perusahaan. Menambahkan jumlah sampel dalam waktu pengamatan yang lebih lama, sehingga diharapkan hasil yang diperoleh akan lebih dapat di generalisasikan.

\section{REFERENSI}

Alvilika, V., Nurlaela, S., \& Samrotun, Y. (2019). Good Corporate Governance Dan Kinerja Keuangan Perusahaan Food And Beverage. EBA Journal: Journal Economics, Bussines and Accounting, 5, 1-10. https://doi.org/10.32492/eba.v5i2.840

Amran, N. A., \& Ahmad, A. C. (2013). Effects of ownership structure on Malaysian companies performance. Asian Journal of Accounting and Governance, 4, 51-60.

Arifani, R. (2012). Pengaruh good corporate governance terhadap kinerja keuangan Perusahaan (studi pada perusahaan yang tercatat di bursa efek indonesia). Jurnal Ilmiah Mahasiswa FEB, 1(2). 
Arosa, B., Iturralde, T., \& Maseda, A. (2012). Board of directors and firm performance in Spanish non-listed family firms. Retrieved from Google Scholar.

Candradewi, I., \& Sedana, I. B. P. (2016). Pengaruh Kepemilikan Manajerial, Kepemilikan Institusional dan Dewan Komisaris Independen Terhadap Return On Asset. E-Jurnal Manajemen Universitas Udayana, 5(5).

Dewi, A. S. (2018). Hubungan Kausal Antara Kepemilikan Manajerial, Dewan Direksi Dan Kinerja Keuangan Pada Perusahaan Manufaktur Yang Terdaftar Di Bursa Efek Indonesia.

Fadillah, A. R. (2017). Analisis Pengaruh Dewan Komisaris Independen, Kepemilikan Manajerial dan Kepemilikan Institusional terhadap Kinerja Perusahaan yang Terdaftar di LQ45. Jurnal Akuntansi, 12(1), 37-52.

Gugong, B. K., Arugu, L. O., \& Dandago, K. I. (2014). The impact of ownership structure on the financial performance of listed insurance firms in Nigeria. International Journal of Academic Research in Accounting, Finance and Management Sciences, 4(1), 409-416.

Gull, A. A., Toquer Akram, M. B., \& Muzaffar, Z. (2013). Do Board Independence Carry Value? A Case Study of Pakistani Banks. Research Journal of Management Sciences ISSN, 2319, 1171.

Halim, A., \& Hanafi, M. M. (2009). Analisis Laporan Keuangan Edisi 4. UPP STIM YKPN. Yogyakarta.

Hermiyetti, H., \& Katlanis, E. (2017). Analisis Pengaruh Kepemilikan Manajerial, Kepemilikan Institusional, Kepemilikan Asing, dan Komite Audit terhadap Kinerja Keuangan Perusahaan. Media Riset Akuntansi, 4(2), Hal-93.

Imam, G., \& Chariri, A. (2007). Teori Akuntansi. Semarang: Badan Penerbit Universitas Diponegoro.

Jusoh, M. A., Ahmad, A., \& Omar, B. (2013). Managerial ownership, audit quality and firm performance in Malaysian. International Journal of Arts and Commerce, 2(10), 45-58.

Kusmayadi, D., Rudiana, D., \& Badruzaman, J. (2015). Good Corporate Governance. Hasil Reviewer, 1-158.

Kutubi, S. S. (2011). Board of director's size, independence and performance: An analysis of private commercial banks in Bangladeshi. World Journal of Social Sciences, 1(4), 159-178.

Larasati, S., Titisari, K. H., \& Nurlaela, S. (2017). Pengaruh Good Corporate Governance Dan Corporate Social Responsibility Terhadap Kinerja Keuangan Perusahaan Manufaktur yang Terdaftar di BEI.

Latief, R., Syed, H., \& Syed, A. (2014). Impact of corporate governance on performance of privatized firms; Evidence from Non-Financial Sector of Pakistan. Middle-East Journal of Scientific Research, 19(3), 360-366.

Masry, M. (2016). The Impact of Institutional Ownership on the Performance of Companies Listed In the Egyptian Stock Market. IOSR Journal of Economics and Finance (IOSR-JEF), 7, 5-15.

Mulyadi, A., TITISARI, K. H., \& NURLAELA, S. (2019). The Effect Of Good Corporate Governance and Capital Structure on Financial Performanve Empiris Study on Consumtion Industrial company year Periode (2015-2017). JURNAL WIDYA GANECWARA, 28(2), 1-11. 
Noviawan, R. A., \& Septiani, A. (2013). Pengaruh mekanisme corporate governance dan Struktur kepemilikan terhadap kinerja keuangan. Fakultas Ekonomika dan Bisnis.

Nuhu, M. S., Umaru, S. Y., \& Salisu, S. (2017). The effect of audit committee's quality on the financial performance of food and beverages industry in Nigeria. International Journal of Business and Management Invention, 6(9), 3240.

Ongore, V. O., \& Owoko, P. (2011). Effects of selected corporate governance characteristics on firm performance: Empirical evidence from Kenya. International Journal of Economics and Financial Issues, 1(3), 99.

Rachmad, A. A. (2013). Pengaruh Penerapan Corporate Governance Berbasis Karakteristik Manajerial Pada Kinerja Perusahaan Manufaktur. E-Jurnal Akuntansi Universitas Udayana, H, 678-696.

Riantono, I. E. (2014). Pengelolaan Manajemen Modern Dalam Mewujudkan Good Corporate Governance: Optimalisasi Pencapaian Tujuan Perusahaan. Binus Business Review, 5(1), 315-322.

Saidu, S. A., \& Gidado, S. (2018). Managerial Ownership and Financial Performance of Listed Manufacturing Firms in Nigeria. International Journal of Academic Research in Business and Social Sciences, 8(9), 1227-1243.

Sekaredi, S., \& Adiwibowo, A. S. (2011). Pengaruh Corporate Governance Terhadap Kinerja Keuangan Perusahaan (Studi Pada Perusahaan yang Terdaftar di LQ45 Tahun 2005-2009). Universitas Diponegoro.

Shah, S. Z. A., \& Hussain, Z. (2012). Impact of ownership structure on firm performance evidence from non-financial listed companies at Karachi Stock Exchange. International Research Journal of Finance and Economics, 84, 6-13.

Subroto, H., Sari, D. I., \& Nurlaela, S. (2016). Pengaruh Good Corporate Governance Terhadap Kinerja Keuangan Perusahaan Real Estate \& Property. Seminar Nasional UNIBA Surakarta, 2(1), 323-332.

Sugiyono, P. D. (2014). Populasi dan sampel. Metode Penelitian Kuantitatif, Kualitatif Dan RED, 291, 292.

Suhardjanto, D., \& Ajibroto, N. (2017). Ownership structure and financial performance: an empirical study of listed airlines industry in Asia and Australia. Review of Integrative Business and Economics Research, 6, 121.

Sujoko, S. (2007). Pengaruh Kepemilikan Saham, Leverage, Terhadap Nilai Perusahaan. Jurnal Manajemen Dan Kewirausahaan, Nomor, 19.

Sulistya, A. F., \& Sukartha, P. D. Y. (2013). Pengaruh Prior Opinion, Pertumbuhan dan Mekanisme Corporate Governance Pada Pemberian Opini Audit Going Concern. E-Jurnal Akuntansi Universitas Udayana, 5, 1732.

Triwinasis, C. R. (2013). Pengaruh Good Corporate Governanceterhadap Kinerja Keuangan (Studi Kasus Pada Perusahaan Perbankan Yang Terdaftar Di Bursa Efek Indonesia Tahun 2011-2012). Universitas Negeri Semarang.

Widyati, M. F. (2013). Pengaruh dewan direksi, komisaris independen, komite audit, kepemilikan manajerial dan kepemilikan institusional terhadap kinerja keuangan. Jurnal Ilmu Manajemen, 1(1), 234-249.

Wiranata, Y. A., \& Nugrahanti, Y. W. (2013). Pengaruh struktur kepemilikan terhadap profitabilitas perusahaan manufaktur di Indonesia. Jurnal 
Akuntansi Dan Keuangan, 15(1), 15-26.

Xin, W. Z. (2014). The impact of ownership structure and capital structure on financial performance of Vietnamese firms. International Business Research, $7(2), 64$.

https://kemenperin.go.id/artikel/20298/Industri-Makanan-dan-Minuman-Jadi Sektor-Kampiun-

www.idx.co.id

www.ojk.co.id 